\title{
Conflict Potency and its Management at Community of Serangan Villlage Unit of Denpasar
}

\author{
I Gede Wardana ${ }^{1}$, Sayu Ketut Sutrisna Dewi ${ }^{2}$ \\ ${ }_{1}^{1}$ Udayana University, Bali, Indonesia, $\triangle$ igedewardana@unud.ac.id \\ ${ }^{2}$ Udayana University, Bali, Indonesia
}

\begin{abstract}
This research is aimed at knowing conflict potency in community and its control/management vertically or horizontally. Had been conducted conflict control efforts and how its management and control model. This research conducted at rural area of Village Unit of Serangan, Denpasar City. Research subject is formal and informal leaders at research location such as Head of Serangan Village Unit, Head of Serangan Traditional Village Unit, Head of campong including Head of Bugis Campong at Serangan Village Unit. The collected data is on community perception in terms of conflict among them conflict potency vertically or horizontally and its control/mangement efforts using methodology of Participation Action Research (PAR). The most dominant conflict potency is as result of project managed by BTID. Really, in the beginning of project had emerged 'tension' because most of community had lost livelihood as fisherman. In deed from such project there is compensation although the income as fisherman is higher. By termination of project then, community more feeling such tension which of opporunity may grow as dispute and hositility or even riots. It is suggested to control conflict early by more intensive dialog between BTID and community to seek out solution received mutually among them by rely on MOU more consistently between BTID and community.
\end{abstract}

Keywords: Conflict potency, control, community and Management

\section{Introduction}

Harmony relations of Serangan Village Unit's community had disturbed again by any inter community problem at Serangan Village Unit on May 1999. Any inter community violence conflict had occured as result of politic conflict facing General Election 1999. Thank to God that such event was not prolonged and its negative impact had not scattered and may be prevented although it has possible larrger violence conflict as result of the development of some existing conflict potency. Proactively, it is required hard efforts to prevent its recurrence. Preventive is more benefit than repressive. This research is aimed at investigating the real problem root as conflict potency and to control it so as not to recuring.

Seemily, Bali which had been recognized as safe province which of community full with tolerant taste is unique when there was riot at such community resulting in fatallity. There is any problematical phenomenon at social system of Bali in general and Serangan Village Unit's community specially. Seemingly, there is any gap between the expectancy of community harmony with discovered reality on violence. Its General Issues is conflict management to community heterogenous and complex community structure. Meanwhile, the community development may not be controlled surely. Its strategic issues are:

a. Really, how structure and function of community social system at Serangan Village Unit from time to time is?

b. The extent to which intensity of conflict potency among social sub system of community at Serangan Village Unit.

c. What is concern and how to muffle and control the community conflict at community of Serangan Village Unit. 
This research is aimed at understanding:

a. The development of structure and function of scommunity social system at Serangan Village Unit from time to time.

b. Intensity of conflict potency among social sub system of community at Serangan Village Unit and the contribution of its role to emerging conflict opportunity

c. The concern and how to muffle and control the conflict by community leaders and such self community of Serangan Village Unit.

Wishfully, this research result may give benefit to hinder the violence conflict by understanding conflict potency and to develop conflict management model at community of Serangan Village Unit specially and Bali Province in general

\section{Conflict and Function Structure Sosiology}

Infrequently, conflict sosiology adopt to distinguish social phenomenon specially upon introduction of development trilogy, one of them is stressed to problem stability in the first five years development. Really, without stability any development may not be realized. Then, by such development and its results any equity will grow, ie, the equity to participate for development and also to enjoy its results simultaneously.

The stability problem is very urgent and when it is correlated with development and national defence problems. There is the relevance and the dependence between stability, development and national defence. The stability will be able to stimulate the opportunity in developing and the developmental results will be able to increase stability of those while stimulating the defence manifestation and conversely, it will be able to maintain the developmental sustainability.

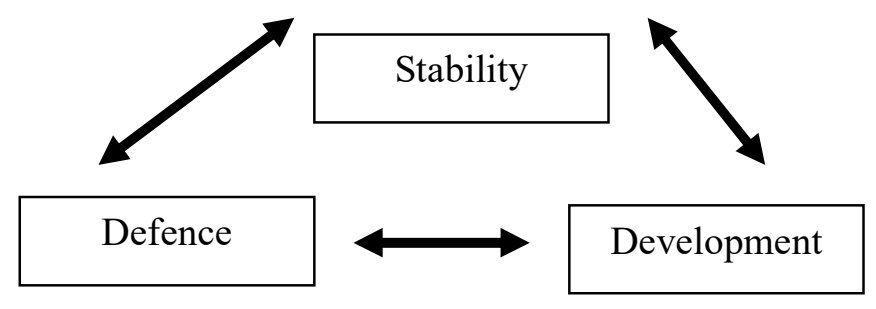

Figure 1 Relevance of Stability, Development and Defence

Then, for sake of stability, more frequently, sociological approach of structural function used for revealing social phenomenon in order to get real picture on inter sub system relevance in any community social system. Each sub system should be able to refrain and maintain integrity of community social system.

By such integralistic approach the stability had been manifested but it is pseudo frequently so that, it had not been illustrated sufficiently and even prohibitted to illustrate the difference between member of any social system resulting in friction and conflict supposedly and even riot will result in fataility. However, it had been confirmed that onflict sociology approach required to complete sociological approach of function structure. By such approach that of conflict sociology may be discovered commenced from the differences which may not be hindered in community life for further information please see Sediono (1997).

Seemingly, the developmental trilogy approach is still relevant to make perception change to contained concept that of stability having not resulted in pseudo stability specially but full dynamical stability. 


\section{Conflict and Its Control}

\section{The Definition of conflict and Its Levels}

Essentially, by concept of "rwa bhineda' in Hinduism community, the human full with the distinctions and those has potency to grow and to be the damaging violence conflict. Hence, it is very important to understand and control each other.

Amstutz, 1982 revealed that "dynamic community life depends on the management not the elimination conflict". To eliminate conflict is impossible but any conflict will result in riot. So, it is required conflict management in order to prevent it and while to grow dynamical community.

And also Amstulz revealed that "'the problem of community is finding an appropriate balance between community order and individual freedom ". "Community order" has close correlation with "harmonious relations", whereas"individual freedom" with "conflict relation" usually, at community the "harmonious relations" is more dominant (8/9) than "conflict relation (1/9) (Figure 2)

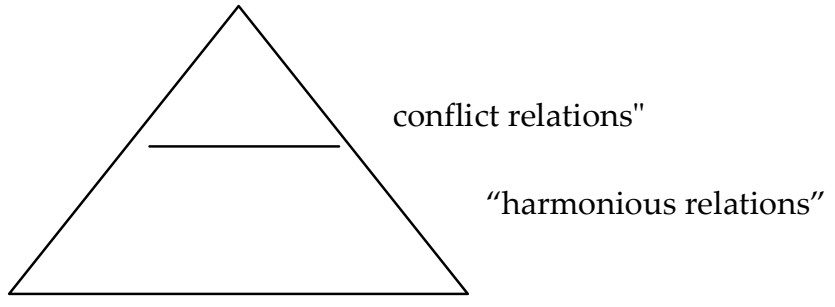

Figure 2 " The Nature of Community Relations ".

Figure 2 illustrate condition of community relations in general. How stable any community is, any inter community conflict relation still may be discovered although not so dominant as result of the difference which may not be hindered possibly. Such conflict relations should be managed in order to have dynamical community. Really, conflict relation may be viewed as developmental resource.

Also Amstutz (1982) revealed that conflict is any continuum of community relations by existing "tension" felt by community as result of the differences to emerging riot or war ("warfare") in community. for more details it may be seen at below.

"Insignificant Incompatibilities"

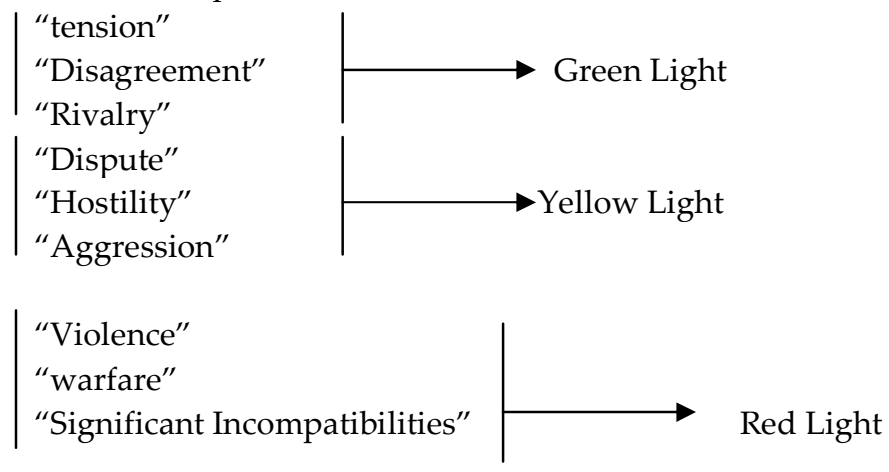

In IRIS (1999) had been revealed the "reframing conflict", where "Conflict is part of life and a natural consequence of differences among people. Conflict can be managed either constructively or destructively: Differences as a resource for development The more options people have to manage conflict, the better able they are to adapt to different situations

\section{Community Attitude Against Conflict}

Also Amstutz, 1982 revealed that conflict is continuum from "tension" through " warfare ". ( Figure 2). IRIS (1999) had revealed the "reframing conflict", i : "Conflict is part of life and a natural consequence of differences among people. Conflict can be managed either constructively or 
destructevily: differences as a resource for development. The more options people have to manage conflict, the better able they are to adapt to different situations."

"Insignificant Incompatibilities"

"tension"

"Disagreement"

"Rivalry"

"Dispute"

"Hostility"

"Aggression"

"Violence"

"warfare"

There is three attitudes to face conflict, those are : no care, muffle and to manage conflict. When conflict had occured then, either by any conflict solver or it may solve automatically. Indeed, it requires understanding of conflict management. Consequently, there is any confusion when there is "violence" or "warfare conflict" harming mutual interest.

Currently, the conflict is muffled and not be managed/controlled. The conflict is stressed and eliminated either by power approach or rights approach". Frequently, any difference is root of conflict problem and by stability reason seemingly, it is taboo to issue or discuss any diffrence. Solely, such attitude requires minimal knowledge on symptom, model and conflict cause. In deed the situation and condition may be stable but it is pseudo frequently.

The attitude to be developed is that of conflict control/ management and it requires high understanding on symptom, model and conflict cause consequently. It requires understanding and appreciation of symptom, model and conflict cause. However it is required any research on conflict management mode. Such conflict management is to let any existing diffrence and even to discuss and direct it in order to result in productive commitment. Then, by concept of "RwaBhineda" any existing difference is supposed normal and maintain it and neither to force to be same.

\section{Dialogue and "Joint Action"}

The attitude to be developed is that of care with conflict and its control, hence, its consequences requires high understanding and appreciation in terms of symptoms, model or conflict trigger.

The conflict control is let existing difference to be discussed hence, it will result in productive commitment. Then, by concept of "Rwa Bhineda" supposedly, the existing differences is normal and even to be maintained but so as not to make same . it is not required stressing on the difference existing in community. Such difference to be controlled and managed.

The expression of andy difference will be able to make clear problem although by the heated debat from there will emerge the solution. Without expression of any difference, it remain uncertain. So that, the solutions may not be sought out easily.

Winston Churchill had said that to do argumentation each other is better than to show military force each other. Continuously to discuss difference transparently, it may result in larger appreciation among individuals or groups bringing about possible conflict potentially. The capability to have disagreement attitude with other opinion but ready to receive and even support other individual or group disagreement right possibly, it will resut in advantage for both parties.

The opened discussion for some differences has advantage among them :

1. To accelerate the launching of thought contribution;

2. To study and restrict some discussion topic;

3. To clear up some emerging problems.

4. To test some alternatives/solutions

5. To prevent veiled hostility; 
6. To bring out and clarify some problems

7. To develop trust and appreciate each other and

8. To muffles the useless conversation

IRIS (1999) revealed "Constructive Conflict management process :"

1. Identification / convening of parties,

2. Identification of Issues,

3. Exploration of values, needs, interests,

4. Creative problem solving,

5. Development of consensus / action - planning

The key of conflict management is dialog and "joint action". Dialog is to develop concensus whereas "joint action" is accordance with the agreed "action planning".

Dialog is any paradigm to be developed in globalization era following understanding paradigm. Understanding Paradigm development in line with information wave may not be hindered easily. The emerged understanding in accordance with information resource trend to be varied and for same problem the understanding is also varied. This variation to be discussed and to develop solution for all parties's benefit/advantage (Medina, 1992).

\section{Social System Development of Bali Community}

Seemingly, slower or faster community social system will changed or developed. The change will be more rapid in facing globalization era by communication and technology and other sectors development. Also to community social system in Bali, in line with the development at its surrounding.

Bali community is highly able to adjust with any change as revealed by Margaret Mead, within Astrid (1986), by observing educatiional process and inter cultural and religious correlatioin. In Bali educatiional process is different with Westerns. Age limit between childrenhood and adults is not separated each other. It result in the children in Ball may enter into adultness without turmoil. It is educatiional process socialization experienced by children in Bali about last 30-40 years. The further problem is educatiional process socialization experienced by now kids in Bali. Is such educatiional process still in model of last 30-40 years?

Elasticity of Bali culture which is able to filter external culture revealed by Carol Warren, within Astrid (1996) by sampling of categorization of traditional rural area and service rural area. Traditional rural area is that solve problem related with tradition, whereas service rural area as only rural area connecting area and rural area population to government. Influence and prestige of traditional rural area is larger compared to those of dinas rural area. However, when Head of service rural area requires decision from population of some tradition rural area, he/she should have permit from service rural area to beat " Kulkul " of traditional rural area as sign that concern of some population of traditional rural area is required to discuss any decision.

\section{Dynamic of Traditional Social Group in Bali}

The difference between traditional ("social ritual") interest with that of service will not influence the achievement of developmental target although by traditional social structure seemingly. It had been revealed by Suyatna (1982) that dynamic of traditional social group in Bali in line with developmental dynamic such as achievement of family planning by "banjar" system and agricultural development by "subak" system. However it had been proposed to maintain and develop traditional social group existing in Bali. Seemingly, it is same as double-edge knife in one side as fortress of cultural value preservation and in other side for accelerating developmental target (Suyatna. 1982).

Dynamic of traditional-social group in Bali is in line with new paradigm of development stressing community empowerment by social management. Essentially, Dynamic of traditional- 
social group in Bali as result of their habits to differ although is in social-ritual problem solely, and transparency for negotiation dialog to seek out solution in owned social-traditional order.

Yasa (19970) revealed the importance of traditional social group in Bali as role of channel to distribute developmental information and as developmenta activities simultaneously.

\section{Methods}

\section{Research Location}

The research conducted at Village Unit of Serangan, sub district of Denpasar Selatan, Denpasar City. Village Unit of Serangan had been elected as research location for obtaining the location which of area growth is rapid other than other consideration.

a. it is proven any violence conflict had occured there

b. it is occupied by genuine population and immigrant supposedly, the interest conflict is large

c. any conflict between BTID and local community.

\section{Data Research}

Wishfully, primary source derived from formal and informal public figures and local community in general. Such formal public figure is from Head of Village Unit through sub village of unit in Serangan village unit, whereas, informal public figure is "bendesa" of traditional village Unit of Serangan as well as "kelian banjar" around there. Also informal leader including Head of LKMD and the figured persons at Village Unit of Serangan, including Head of "Sekaa Teruna" at Village Unit of Serangan. Secondary Data obtained from profile book of village unit and other resources.

\section{Approach, Data and Data Analysis}

The approach used in this research is that of history, culture, and structural-functional sociology as well as conflict sociology approach. By historical and cultural approach wil be obtained data on the development of social-cultural system at community of Serangan Village Unit including physical culture. Subsequently, by structural-functional sociology will be obtained some sub-systerns in community social system in Village Unit of Serangan. By conflict sociology approach will be obtained data on factors felt had scotched community either genuine or immigrant community, finally, it has opportunity to result in violence conflict or riot.

The collected data centralized on data of blocage had been felt by community at Serangan Village Unit. Subsequently, how community respond those. Those data obtained from interview deeply with research methodology of Participation Action Research (PAR).

PAR methodology had been utiilized as result of using model of community empoverment in the development as revealed by Loekman Soetrisno (1997). By such PAR methodology had placed the community as partner and not as research object.

Quantitative analysis will be applied for processing collected data by describing social system of community at Serangan village unit as transparent as possible and its development. . Sociogram is any method which will be applied to illustrate public figure character at community. The analysis directed to conflict potency and its prevention or stoppage.

\section{Research Schedule}

It is required early research and its result to test mindset and used research method. True research had been implemented gradually from approach of structural-functional socilogy abviously, it may illustrate the development of structure and function of sociological approach at village unit of Serangan. Subsequently, by conflict sociological and social psychology approaches wishfully, it may illustrate the factors of conflict trigger and the opportunity of community integration at Serangan village Unit. The research result will be utilized to build dynamical Serangan village Unit. Research schedule presented at Table 1 


\section{Results and Discussion \\ Short Illustration of Village Unit of Serangan}

Width of Village Unit of Serangan is 101 hectares bordered in the northern with, Village Unit of Tanjung Benoa, in the southern with Village Unit of Pedengan and in the eastern with selat Badung, by existence of BTID project.

Its geographical condition has coastal topography, hence, the livelihood dominated by fisherman. Total population described in Table 1

Table 1 Population According to Livelihood

\begin{tabular}{clc}
\hline Num. & \multicolumn{1}{c}{ Livelihood } & Persons \\
\hline 1. & Employee : & \\
& a. Civil Servant & 23 \\
& b. Armed Force & - \\
& c. Private Employees & 65 \\
\hline 2 & Entrepreneur / Merchant & 433 \\
\hline 3 & Farmer & 75 \\
\hline 4. & Handicraft & 50 \\
\hline 5 & Farm workers & - \\
\hline 6. & Pension & - \\
\hline 7. & Fisherman & 990 \\
\hline 8 & Scavenger & - \\
\hline 9. & Servicer & - \\
\hline & Total & 1.636 \\
\hline
\end{tabular}

Source : Monograph Data from Rural Area and Village Unit of Serangan, December 1998

Total population of Village Unit of Serangan are 2,875 persons from 664 Family Heads. From those the most dominant is Hinduism (2,663 persons ) followed with Moslem (203 persons ) and Catholic ( 9 persons ). There are 18 castles including Castle of Sakenan and 1 Mosque located at area of Kampung Bugis.

Seemingly, in political arena, there is dominance shift from Golkar to PDI Perjuangan. In General Election of 1997, Golkar was the winners with 1.181 votes, whereas, PDI and PPP was 491 votes and and 76 votes. In General Election of 1999, PDI Perjuangan was most dominant followed by Golkar and other parties. Golkar PDI Perjuangan had competed strictly. (Table 2)

Table 2 Votes of Political Party in General Election of 1999

\begin{tabular}{clccc}
\hline Numb. & Name of Political Party & DPR & DPR. I & DPR. II \\
\hline 1. & PDI Perjuangan & 864 & 842 & 845 \\
\hline 2. & Golkar & 778 & 788 & 760 \\
\hline 3. & P.R & 49 & 52 & 55 \\
\hline 4. & P.N.I & 61 & 80 & 87 \\
\hline 5. & P.A.N & 31 & 27 & 27 \\
\hline 6. & P.D.I & 1 & 3 & 1 \\
\hline
\end{tabular}

Notes: $\quad$ DPR is House of Representative at State

DPR I is House of Representative at Province

DPR II is House of Representative at City/Regency

Source: Village Unit of Serangan.

Then, by project of BTID there is change of natural stretch as result of large coastal accumulation as well as close relationship between land and islands of Serangan. Seemingly, this BTID project as 
prominent change which has opportunity to result new issues bringing about friction in the midst of community.

Then, by observing Table 1, main occupational clustering is fisherman and merchant. New stretching of Serangan resulted from BTID project, it is related with such large group specially. The happiness of group of fishermen will be disturbed by it, but, other fisherman group at offshore specially they will not be disturbed by such stretching and they will be confortable in preparing their boats specially. By such stretching at Serangan the merchants and other communities will get transportation convenience.

By considering those three factors resulting in community unharmonious then, also community structure will be sorted to be three large group, those are: (1) Social-economic factor (2) religious and social-cultural factor (3) social-political factor.

Seemingly by considering economic-social factor there is community faced to BTID. Vertically, by considering social-cultural and Hinduism factors there is a winning and losing community, seemingly, community structure divided into Hinduism Bali ethnic and Islam Bugis ethnic. Vertically, its structure had not been conspicuous but by considering social-political factor seemingly, it is sorted among certain political ideology followers. And also, vertically, it was conspicuous between village unit apparatus and large public in the early reform era (1997) specially. Illustration of conspicuous social structural system of community related with conflict potency is described in table 3 .

Table 3 Illustration of Community Social System Structure of Village Unit of Serangan.

\begin{tabular}{lll}
\hline \multicolumn{1}{c}{$\begin{array}{c}\text { Aspect of Conflict } \\
\text { Resource }\end{array}$} & \multicolumn{1}{c}{ Conflict Direction at Community } \\
\cline { 2 - 3 } Social-Politic & Apparatus and Community & \multicolumn{1}{c}{$\begin{array}{l}\text { Inter ideology followers and } \\
\text { political party in the midst of } \\
\text { community }\end{array}$} \\
\hline Social-Economic & $\begin{array}{l}\text { Developed and } \\
\text { Undeveloped economic }\end{array}$ & $\begin{array}{l}\text { Community with BTID project } \\
\text { party }\end{array}$ \\
\hline $\begin{array}{l}\text { Social-Cultural } \\
\text { Religion }\end{array}$ & $\begin{array}{l}\text { Community Public Figures } \\
\text { and Followers }\end{array}$ & \begin{tabular}{l} 
Inter ethnic and Religion \\
\hline
\end{tabular} \\
\hline
\end{tabular}

\section{Conflict potency and Its Control/Management}

Perception on Conflict

Conflict always be understood as violence conflict and physical impact and riots, hence, it is always hindered to discuss conflict, the violence conflict had ever occurred facing general election of 1999 specially.

Wholly, either the leader(s) or even community at Village Unit of Serangan had not understood that conflict may be managed in order to bring about dynamical community. Really, the conflict just had arrived at stages of "tension" or "disagreement" through "rivalry", it may be managed and utilized to be dynamical community.

By lack of comprehension in terms of conflict and its control, then, some conflict potentials will bring about "violence conflict" and even riots will harm community in general. Conflict potency may emerge as result of tensions of Social-Economic , Social-Cultural and Religion as well as politic vertically or horizontally.

\section{Vertical Conflict}

Transparently, since the beginning of reform era the "tension" had emerged and developed to be "disagreement" between large community and village unit head. disagreement feeling of community against their village unit head had been emerged openly, rapidly, it had been responded by major hence, village unit head succession had been implemented twice. Coincidently, the present ad hoc village unit head derived from Serangan and he had been received by community seemingly, hence, its inauguration should be accelerated. Community expectation should be responded by Major 
rapidly. Seemingly, vertical conflict as result of Social-Political factor had not been conspicuous as well as vertical conflict as result of Social-Cultural and Religion factors.

Community openness to reveal the "disagreement to their village unit head in this case is potency to seek out problem solving. Seemingly, disagreement had not been supposed as enemy, so that, it had not required repressive action. The transparency of community attitude it makes easier to develop dialog in order to seek out solution by dismissing two village unit heads in the near time.

Seemingly, there had emerged 'tension' in vertical conflict potency as result of Social-Economic factor. Some community members had developed their economic successfully but some others not. The rivalry feeling of them had emerged and even it had increased to be hard rivalry. By lack of comprehension in terms of conflict and its control or management then, such potency may develop to be violence conflict, moreover it had became "rivalry" and even "aggression" level. Possibily, it may be said that such situation had arrived at yellow light situation by considering vertical conflict potency of Social-Economic aspect.

\section{Horizontal Conflict}

Seemingly, the most conspicuous potency of horizontal conflict is Social-Economic aspect and then Social-Politic aspect. Seemingly, no tension in Social-Cultural and Religion aspects.

Any neighborhood unit (RT) at Kampung Bugis of Village Unit of Serangan dominated by Moslems has one (1) mosque. Seemingly, mix and plurality concepts had been implemented simultaneously. It was proven by among community always assist each other when there were activities at village unit milieu such as "odalan" ceremony at Castle of Sakenan. Most of community members also had participated in supporting activities of ceremony and even by complete Bali traditional clothing. Nevertheless, they implemented plurality concept in which each community member may implement their religious belief. Bugis ethnic who follow Islam Religion has one (1) mosque and Bali Ethnic has one (1) castle.

Seemingly, from Social-Politic aspect there is "tension" among organizational member of SocialPolitic and even there was violence conflict in facing General Election in 1999. Social-Politic aspect always be recurrence "tension" for once five years, additionally, the power of existing Social-Politic is balanced enough and had never managed or controlled the conflict commenced from the difference.

Seemingly, the difference of political ideology may not be eliminated easily, hence, it is difficult to seek out the solution. The opportunity to result in violence conflict is large moreover it had ever experienced in general election of 1999.

Seemingly, the dominance of organizational power of Social-Politic had fluctuated. In 1965 the winner is PNI (Indonesia National Party) and there was all about Golkar (Functional Group Party) in 1971 and as a result, Golkar had wined the election in 1997 but, it 1999 PDI Perjuangan (Indonesia Democratic Party of Struggle) had wined. The most conspicuous horizontal conflict of conflict potency is derived from Social-Economic aspect between BTID project with community. Indeed, its control/management had been sought out based on MOU made for each dialog implementation. Such potency is very positivie because the success or not of BTID project it remain resulting in the conflict .

The illustration of conflict potency at Village Unit of is described in table 4.

Table 4 Ilustration of Conflict Potency at Village Unit of Serangan

\begin{tabular}{lccc}
\hline & Vertical & \multicolumn{2}{c}{ Horizontal } \\
\hline Social-Politic & - & \pm \\
\hline Social-Economic & \pm & + \\
\hline Social-Cultural dan Religion & - & - \\
\hline
\end{tabular}




\section{Management and Conflict Control Model}

Seemingly, currently, there was no efforts for managing conflict to make the difference as developmental resource consciously. Nevertheless, the dialogs had been made but it was not part of keyword for managing/controlling the conflict.

Violence conflict had ever occurred solely, it had been submitted to apparatus and law enforcer. This approach is that always be adopted in Indonesia in general, ie, "power approach " and "right approach". There was not approach based on "values", "needs", or even "interest". Conflict potency of Social-Politic is horizontal in nature, reasonably, it should be dialoged among community to seek out the solution in order that the difference of political ideology may be maintained and it will result in the competition will grow dynamical community. Unfortunately, it had never been realized.

Conflict potency of Social-Economic in Vertical nature also had never sought out the solution consciously. Frequently, the anxious feeling in terms of jealousy feeling among community had scared the community and infrequently, it had been accompanied with "black magic" issues . All "tensions" of Social-Economic will stay as "tension" and even had developed to be "disagreement" and "rivalry". It is required the meeting to seek out solution hence, it may be utilized as developmental resource. The success of some community members should be adopted to motivate other community members.

The solution of conflict potency of Social-Economic in horizontal should be sought out by initiating the dialog between community and BTID based on MOU having been agreed. It is any solution having been implemented from such dialog as well as the problems which will emerge since then. Seemingly, it always develops as result of dilemma faced by BTID project. Seemingly, to return Serangan condition as its origin is very difficult and also impossible. But either it is stopped or continues, it remains the problem which harm all parties. As result of such dilemmatic condition then, it is required intensive dialog, additionally, the existing "tension" had developed to be "aggression"one such as land looting. The solution by dialog is very good and it just had increased its intensiveness by assistance of mediator, hence, of course, the resultant conflict may be utilized as developmental resource for developing community. It is required social manager who have hero spirit without payment to struggle the peaceful of community as revealed by Felix (1999).

\section{Conclusion}

a. Conspicuous structure of community as result of unharmonious factors of Social-Politic, SocialEconomic and Social-Cultural -Religion:

- Sub system of community had conformed with political ideology followed by community of Village Unit of Serangan. a.2. Sub system community who's economic had developed and who had not developed and other large community with project of BTID.

- Sub system community of Hinduism Bali ethnic with sub system community of Islam Bugis ethnic at Village Unit of Serangan.

b. The most conspicuous conflict potency is that between BTID project and community in general.

c. Community comprehension on conflict and conflict management is less and generally, the conflict had been viewed as violence conflict.

\section{References}

Amstutz Mark R. (1982). An Introduction to Political Science. The Management of Conflict. Scott. Glenview, Illinois. Foreman and Company.

Arifin Pandigoro (Dr. Hc). "Melawan Lupa". Graduate Program, Study Program of American Territory, IASTH Building, 3rd floor, University of Indonesia - Salemba

Bali Post, (1997) a. Sepersons Terbunuh, Massa Mengamuk. Bali Post, Rabu Kliwon. 22 Oktober 1997. page 15. Denpasar.

Bali Post, (1997) b. "Di Balik Terbunuhnya Wayan Kayun. Tak Ada Musyawarah. Pelaku Harus Diadili." Bali Post, Thursday, pon, 25 October 1997, page 19. Denpasar. 
Boediono. Mekanisme Fungsional Sistem Ekonomi Pancasila

Felix Sitorus MT, (1999), "Pendekatan Manajemen Sosial Dalam Pengembangan Community ". Discussion Minor Paper of Ikatan Sosiologi Indonesia (ISI) in scope of inaugurating Central Board of ISI and Induction of ISI Branch of Bogor, in Bogor.

Indonesia", in sociology journal of Indonesia. No.2, September 1997.

IRIS. (1999) "Constructive Conflict Management: Building Foundations for Sustainable Development Institute for Social and Economic Research at University of Indonesia

IRiS. (1999). Constructive Conflict Management. Building Foundations for Sustainable. Development Institute for Social ang Economic Research at University of Indonesia.

Koentjaraningrat, (1985). Persepsi Kebudayaan Nasional. Persepsi Community tentang Kebudayaan. (Alfian, ed.) Jakarta.

Loekman Soetrisno, (1997). Pemberdayaan Community Desa dan Masalahnya di Indonesia Bengkulu.

Medina, Carlue R. (1992). From Evaluationto Meaning. From Meaning to Dialogeu. A. Paradigma Sift in Undestanding Religion. Makalah yang disampaikan pada The Scond International Conference on Research and Development in the Brave New World. Futuristic Perspeethe at Thailand Cultural Centre, Bangkok, 9-I I November 1992.

Medina, Carlve R. (1992). "From Evolution to Meaning, From Meaning to Dialouge; A Paradigma Sift in Understanding Religion. Makalah disampaikan pada The Second International Conference on Research and Development in the Brave New World, Futuristic Perspective at Thailand Cultural Centre, Bangkok 9-11 November 1992.

Mubyarto. Dasar-Dasar Ideologi Filsafat dan Nilai-Nilai Sistem Ekonomi Pancasila.

Murya Anak Agung Putu, A.A. Gede Ngurah Mayun Inggas. A.A. Ngurah Oka, (1993). Sejarah Ptiri Pemecutan Badung. Puri Agung Pemecutan.

Pelly Usman, (1992) "Pengukuran Intensitas Potensi Konflik Dalam Masyarakat Majemuk", dalam Analisis CSIS, Potensi Konflik, Centre for Starregic and International Studies, Year of XXII No.3 Mei - June 1993.

Pelly Usman, (1992). Pengukuran Intensitas Potensi Konflik dalam Masyarakat Majemuk dalam Analisis CSIS. Potensi Konflik . Centre for Strategic and Interjnational Studies. Tahun XXII No. 3 Mci Juni 1993.

Sedionao M.P. Tjondronegoro, (1997). Gejala Konflik dalam Ilmu Sosiologi Indonesia, dalarn Juriial Sosiologi Indonesia, No. 2/September 1997.

Sediono MP Tjondronegoro, (1997) “Gejala Konflik Dalam Ilmu Sosiologi

Sidemen Ida Bagus, I Nyoman Suaryana, F.X. Soenaryo, I Made Sudjana. Sulandjari. penyustin. (1992). Sejarah Badung 1779-1906. Second Level of Local Government of Badung Regency.

Sutopo Yuwono, (Let. Jen TNI Pur) . Sistem Ekonomi Pansila dan Ketahanan Nasional

Suyatna, (1982). Ciri-ciri Kelompok Sosial Tradisional di Bali dan Peranannya dalam Pembangunari Diterbitkan oleh IPB Bogor.

Suyatna, I Gde, (1982), Ciri-ciri Kelompok Sosial Tradisional di Bali dan Peranannya Dalam Pembangunan, issued by IPB Bogor.

Tim Peneliti Sejarah Masuknya islam di Bali, 1979/1980. Sejarah Masuknya Islam di Bali. Report of Research Project of First Level Region of Bali Province .

Yasa, I Made,(1997), “Potensi Banjar Sebagai Wahana Pembangunan Bali”, Disertasi Doktor. Graduate Program of IPB Bogor. 